\title{
THE INFLUENCE OF ENVIRONMENTAL FACTORS ON THE PLANKTONIC GROWTH AND BIOFILM FORMATION OF Escherichia coli
}

\author{
Katarina G. Mladenović ${ }^{*}$, Mirjana Ž. Muruzović1, \\ Tanja D. Žugić-Petrović ${ }^{2}$ Ljiljana R. Čomić1 \\ ${ }^{1}$ University of Kragujevac, Faculty of Science, Department of Biology and Ecology, \\ Radoja Domanovića 12, 34000 Kragujevac, Republic of Serbia \\ ${ }^{2}$ College of Agriculture and Food Technology, Cirila and Metodija 1, \\ 18400 Prokuplje, Republic of Serbia \\ *Corresponding author; E-mail: katarinamladenovic90@gmail.com
}

(Received January 8, 2018; Accepted May 17, 2018)

\begin{abstract}
In this study, the effects of environmental factors (different media, temperature, $\mathrm{pH}$, salt and sugar concentrations) on the planktonic growth, biofilm formation and formed biofilm of Escherichia coli KGPMF 16 and Escherichia coli KGPMF 17 were investigated. Tested bacteria were isolated from traditionally made cheese produced in Southeastern Serbia (Sokobanja region). The influence on planktonic growth, biofilm formation and formed biofilm was determined using spectrophotometric method. The limiting factors for the planktonic growth and biofilm formation were temperature of $4{ }^{\circ} \mathrm{C}$ and all tested concentrations of salt. The growth of tested bacteria was higher in media enriched with lactose than in media containing glucose. TSB was more congenial media to the planktonic growth of bacteria than MHB broth. None of the tested bacteria demonstrated the ability to form biofilm at $4{ }^{\circ} \mathrm{C}$ and $44{ }^{\circ} \mathrm{C}$. Only E. coli KGPMF 17 showed ability to form biofilm in TSB at $37^{\circ} \mathrm{C}$. Different concentrations of salt, glucose and lactose exhibited inhibitory effect on biofilm formation, but all tested concentrations of lactose showed stimulating effect on formed biofilm of $E$. coli KGPMF 17. These results contribute to better understanding of the effects of environmental factors on the development of $E$. coli in cheese.
\end{abstract}

Keywords: biofilm formation, E. coli, planktonic growth, traditionally made cheese.

\section{INTRODUCTION}

Escherichia coli is one of the members of the microbiota of the intestinal flora. With other bacteria, they contribute $0.1 \%$ to the total flora (ECKBURG et al., 2005). E. coli possesses the ability to survive outside the host for a certain time which makes it an important indicator of environmental condition (FENG et al., 2002). ISHII and SADOWSKY (2008) confirmed that resistant $E$. coli may survive very long outside the host.

Environmental factors, such as concentration of nutrients, osmotic pressure, temperature, etc., affect bacteria in their environment (BRENHORVD et al., 1992; BOUCHER et 
al., 1994). In the environment, bacteria are more frequently found in biofilms than in planktonic (free-living) forms (HALL-STOODLEY et al., 2004; HARRISON et al., 2007). These biofilms are generally described as microbial cells attached to a surface and encased in an extracellular polysaccharide matrix (COSTERTON et al., 1995). Several factors such as pH, temperature, concentration of $\mathrm{O}_{2}$ and glucose can affect biofilm formation (COSTA et al., 2014). Biofilms demonstrate greater resistance to antimicrobial agents (XU et al., 2000) which is significant due to the fact that biofilms cause food spoilage during production in food industry (TRÉMOULET et al., 2002). Many investigations indicated that the temperature, type of medium and other growth conditions determined which genes were induced or repressed during biofilm development (SCHEMBRI et al., 2003; BELOIN et al., 2004; REN et al., 2004; DOMKA et al., 2007). According NESSE et al. (2014) potentially human-pathogenic E. coli from the ovine reservoir can form biofilm on various surfaces and at several temperatures relevant for food.

The aim of this study was to investigate the planktonic growth and ability of the bacteria from the genera Escherichia (E. coli KGPMF 16 and E. coli KGPMF 17) from autochthonous cheese, to form biofilm in two different broths, under the influence of different temperatures, $\mathrm{pH}$, concentrations of $\mathrm{NaCl}$, glucose and lactose, as well as the impact of the mentioned environmental factors on the formed biofilm.

\section{MATERIALS AND METHODS}

\section{Strains and growth conditions}

Bacteria used in this study were E. coli KGPMF 16 and E. coli KGPMF 17. E. coli ATCC 25922 was used as a positive control. The bacteria were previously isolated from Serbian cheese (Sokobanja region) and determined at the Laboratory for Microbiology at the Faculty of Science, University of Kragujevac (KGPMF) (MLADENOVIĆ et al., 2018). The collection of identified bacterial species was kept in a $20 \%$ glycerol/medium mixture at -80 ${ }^{\circ} \mathrm{C}$.

\section{The effect of different temperatures on the planktonic growth of tested bacteria}

The examination of the effect of temperature on the growth of tested bacteria was conducted in Tryptic soy broth (TSB) (Merck, KGaA, Darmstadt, Germany) and MullerHinton broth (MHB) (Torlak, Serbia) of standard or modified compositions. These two broths were used due to their different composition and different influence on the bacterial growth. $10 \mu \mathrm{l}$ of initial bacterial suspension $\left(10^{8}-10^{9} \mathrm{CFU} / \mathrm{ml}\right)$ was added to $3 \mathrm{ml}$ of each type of media. All samples were prepared in triplicate, each for one tested temperature $\left(4{ }^{\circ} \mathrm{C}, 37{ }^{\circ} \mathrm{C}\right.$, $44{ }^{\circ} \mathrm{C}$ ). The samples were incubated for $24 \mathrm{~h}$. Pure TSB and MHB served as sterility controls. The results were obtained using spectrophotometer (SPEKOL 21, MA 9521, Iskra, Kranj, Slovenia) at $600 \mathrm{~nm}$. Each experiment was performed in triplicate.

\section{The effect of different $\mathrm{pH}$ and different concentrations of $\mathrm{NaCl}$}

For examining the effect of $\mathrm{pH}$, the media whose $\mathrm{pH}$ values were 5.5, 6.5, 7, 7.5 and 8.5, were prepared. After adding $\mathrm{HCl}$, acidic and neutral media were obtained $(\mathrm{pH} 5.5,6.5$ and 7), while after adding $\mathrm{NaOH}$, we obtained basic media ( $\mathrm{pH} 7.5$ and 8.5). For TSB, the growth control was $\mathrm{pH} 7.5$, while for MHB, growth control was $\mathrm{pH}$ 7. The effects of different salt concentrations were investigated in modified media with the addition of $\mathrm{NaCl}(4 \%, 6.5 \%$ and $8 \%$ ). Growth in TSB containing $4 \% \mathrm{NaCl}$ and in pure MHB served as growth controls. In $3 \mathrm{ml}$ of each type of modified media, $10 \mu \mathrm{l}$ of initial bacterial suspension $\left(10^{8}-10^{9} \mathrm{CFU} / \mathrm{ml}\right)$ 
was added. The samples were incubated at $4{ }^{\circ} \mathrm{C}, 37{ }^{\circ} \mathrm{C}$ and $44{ }^{\circ} \mathrm{C}$ for $24 \mathrm{~h}$. The results were obtained using spectrophotometer at $600 \mathrm{~nm}$. Each experiment was performed in triplicate.

\section{The effect of different concentrations of glucose and lactose}

To modified TSB and MHB, different concentrations of glucose and lactose $(0.5 \%$, $1.5 \%, 2.5 \%$ and $3.5 \%)$ were added, respectively. $10 \mu \mathrm{l}$ of initial bacterial suspension $\left(10^{8}-10^{9}\right.$ $\mathrm{CFU} / \mathrm{ml}$ ) was added to $3 \mathrm{ml}$ of each type of media. All samples were prepared in triplicate, each for one of tested temperatures $\left(4^{\circ} \mathrm{C}, 37{ }^{\circ} \mathrm{C}\right.$ and $\left.44{ }^{\circ} \mathrm{C}\right)$. The samples were incubated for $24 \mathrm{~h}$. Growth and sterility controls were prepared, as well. The results were obtained using spectrophotometer at $600 \mathrm{~nm}$. Each experiment was performed in triplicate. Growth in TSB containing $0.25 \%$ of glucose $(\mathrm{pH} \mathrm{7.5)}$ and in pure MHB served as growth controls for growth of bacteria in glucose and lactose.

\section{Determination of antibiofilm activity}

\section{Pellicle test}

The ability to form a biofilm phenotype or pellicle formation on the air-liquid interphase was demonstrated using pellicle assay in accordance with the method already described (VESTBY et al., 2009), with modifications. $1.8 \mathrm{ml}$ of TSB and MHB were inoculated with $0.2 \mathrm{ml}$ of each isolate suspension, and then incubated for $96 \mathrm{~h}$ at $37{ }^{\circ} \mathrm{C}$. The categorization of isolates and their ability to produce the biofilm were based on the production of pellicle on the surface of the liquid phase according to the following scheme: the solid fat formed pellicle $(+++)$ - a good biofilm producer, a thin pellicle formed $(++)$ - a moderate biofilm producer, very thin pellicle $(+)$ - a weak biofilm producer, a complete absence of pellicle (-) - the absence of ability to produce the biofilm. Pellicle test was repeated three times for each tested isolate.

\section{Biofilm formation assay and quantification}

The ability of E. coli KGPMF 16, E. coli KGPMF 17 and E. coli ATCC 25922 to form biofilms at $4{ }^{\circ} \mathrm{C}, 37^{\circ} \mathrm{C}$ and $44{ }^{\circ} \mathrm{C}$, was assayed by O'TOOLE AND KOLTER (1998), with some modifications.

Two different broths (TSB or MHB) were used for the experiment. In sterile 96-well tissue culture plates (Sarstedt, Nümbrecht, Germany) containing $100 \mu \mathrm{l}$ of modified broth per well (with different $\mathrm{pH}$, different concentration of salt, glucose and lactose), $10 \mu \mathrm{l}$ of fresh bacterial suspension (1.0 McFarland) was added. After incubation at $37{ }^{\circ} \mathrm{C}$ for $48 \mathrm{~h}$, the content of each well was gently removed by tapping the plates. The wells were washed with $200 \mu \mathrm{l}$ of sterile saline to remove free-floating bacteria. Biofilms formed by adherent cells in plate were fixed with $100 \mu \mathrm{l}$ of methanol, and then stained with $100 \mu 1(0.1 \%)$ of crystal violet and incubated at the room temperature for $20 \mathrm{~min}$. Excess stain was rinsed off by thorough washing three times with $200 \mu \mathrm{l}$ deionized water and then fixed with $100 \mu \mathrm{l}$ of $96 \%$ ethanol. Optical densities (ODs) of stained adherent bacteria were determined using an enzyme-linked immunosorbent assay (ELISA) plate reader (RT-2100C, Rayto, Shenzhen, China) at $630 \mathrm{~nm}$.

A sterile broth with different concentration of $\mathrm{pH}, \mathrm{NaCl}$ and sugar served as control for checking sterility and nonspecific binding of media. In order to neutralize background absorbance, OD readings from sterile medium, modified broth, fixative, and dye were calculated and subtracted from all test values. All tests were performed in triplicate and their mean value was calculated. 


\section{The effect on formed biofilm}

The tissue culture 96-well microtiter plates (Sarstedt, Nümbrecht, Germany) were prepared by dispensing $100 \mu \mathrm{l}$ of TSB or MHB. $10 \mu \mathrm{l}$ of fresh bacterial suspension (1.0 McFarland) was added into each well. The inoculated microtiter plates were incubated at 37 ${ }^{\circ} \mathrm{C}$ for $24 \mathrm{~h}$. After the incubation, the content of each well was gently pulled out. Then, $100 \mu \mathrm{l}$ of modified broth, which contained different $\mathrm{pH}$, different concentration of salt, glucose and lactose was added and inoculated microtiter plates were incubated at $37^{\circ} \mathrm{C}$ for $24 \mathrm{~h}$. After the incubation, the content of each well was gently removed by tapping the microtiter plates. The rest of the experiment was performed as described above.

\section{Data analysis}

All data were presented as means \pm standard deviations using Microsoft Excel (Redmond, Washington, DC, USA).

\section{RESULTS}

\section{The influence of different temperature, $\mathrm{pH}, \mathrm{NaCl}$, glucose and lactose concentrations on the planktonic growth of tested bacteria}

Tested bacteria were incubated in different media at three different temperatures (4 ${ }^{\circ} \mathrm{C}, 37{ }^{\circ} \mathrm{C}$ and $44{ }^{\circ} \mathrm{C}$ ). After the incubation, it was noticed that there was no growth at $4{ }^{\circ} \mathrm{C}$.

In TSB at $37^{\circ} \mathrm{C}$, the growth of $E$. coli KGPMF 16 was reduced in all $\mathrm{pH}$, except in $\mathrm{pH}$ 8.5 , where growth was higher compared to the growth control. The growth of E. coli KGPMF 17 and E. coli ATCC 25922 was reduced in $\mathrm{pH} 5.5$ and 6.5, while in other tested $\mathrm{pH}$ growth was similar as growth control. In MHB at $37{ }^{\circ} \mathrm{C}$, the growth of E. coli KGPMF 16 was reduced in all tested $\mathrm{pH}$, except in $\mathrm{pH} 7.5$, where growth was equal to the growth control. The growth of E. coli KGPMF 17 was reduced in $\mathrm{pH} 5.5$ and 8.5, while growth of E. coli ATCC 25922 was reduced in all tested $\mathrm{pH}$, except in $\mathrm{pH} 6.5$.

In TSB at $44{ }^{\circ} \mathrm{C}$, growth of E. coli KGPMF 16, E. coli KGPMF 17 and E. coli ATCC 25922 was reduced in all tested $\mathrm{pH}$, except 8.5. In MHB, at $44{ }^{\circ} \mathrm{C}$, growth of $E$. coli KGPMF 16 was reduced in $\mathrm{pH} 5.5$ and 8.5, but in $\mathrm{pH} 6.5$, the growth was stimulated. The growth of $E$. coli KGPMF 17 and E. coli ATCC 25922 was reduced in all pH, except in pH 6.5 (Tab. 1).

All tested salt concentrations in TSB and MHB produced reducing effect on the planktonic growth of E. coli KGPMF 16, E. coli KGPMF 17 and E. coli ATCC 25922, at both tested temperatures $\left(37^{\circ} \mathrm{C}\right.$ and $\left.44^{\circ} \mathrm{C}\right)$ (Tab. 2).

All tested concentrations of glucose in TSB at $37{ }^{\circ} \mathrm{C}$ demonstrated reducing effect on the planktonic growth of E. coli KGPMF 16, E. coli KGPMF 17 and E. coli ATCC 25922. In MHB with different concentrations of glucose, at $37^{\circ} \mathrm{C}$, the growth of $E$. coli KGPMF 16 was reduced. The growth of $E$. coli KGPMF 17 was stimulated in all concentrations, except in $1.5 \%$, while the growth of E. coli ATCC 25922 was reduced in all concentrations, except in $2.5 \%$.

In TSB containing different concentrations of glucose, at $44{ }^{\circ} \mathrm{C}$, growth of $E$. coli KGPMF 16, E. coli KGPMF 17 and E. coli ATCC 25922 was reduced. Exception is $0.5 \%$ of glucose, where growth of E. coli ATCC 25922 was stimulated. MHB containing $2.5 \%$ and $3.5 \%$ of glucose was stimulating for E. coli KGPMF 16 at $44{ }^{\circ} \mathrm{C}$, while the growth of E. coli KGPMF 17 and E. coli ATCC 25922 was stimulated in all other pH (Tab. 3). 
Table 1. The effect of different $\mathrm{pH}$ on the planktonic growth.

\begin{tabular}{|c|c|c|c|c|c|c|c|c|c|c|}
\hline \multirow[b]{2}{*}{ Species } & \multicolumn{5}{|c|}{ TSB at $37^{\circ} \mathrm{C}$} & \multicolumn{5}{|c|}{ MHB at $37^{\circ} \mathrm{C}$} \\
\hline & 5.5 & 6.5 & 7 & $7.5^{*}$ & 8.5 & 5.5 & 6.5 & $7 *$ & 7.5 & 8.5 \\
\hline E. coli KGPMF 16 & $0.01 \pm 0.00$ & $0.67 \pm 0.01$ & $0.80 \pm 0.01$ & $1.04 \pm 0.01$ & $1.41 \pm 0.02$ & $0.05 \pm 0.00$ & $0.70 \pm 0.10$ & $0.80 \pm 0.01$ & $0.80 \pm 0.00$ & $0.62 \pm 0.01$ \\
\hline E. coli KGPMF 17 & $0.02 \pm 0.00$ & $1.46 \pm 0.04$ & $1.63 \pm 0.01$ & $1.64 \pm 0.00$ & $1.60 \pm 0.00$ & $0.06 \pm 0.02$ & $0.70 \pm 0.01$ & $0.70 \pm 0.03$ & $0.70 \pm 0.01$ & $0.40 \pm 0.06$ \\
\hline E. coli ATCC 25922 & $0.03 \pm 0.00$ & $1.19 \pm 0.04$ & $1.76 \pm 0.01$ & $1.72 \pm 0.02$ & $1.68 \pm 0.01$ & $0.05 \pm 0.00$ & $0.82 \pm 0.04$ & $0.75 \pm 0.01$ & $0.66 \pm 0.00$ & $0.45 \pm 0.00$ \\
\hline & \multicolumn{5}{|c|}{ TSB at $44^{\circ} \mathrm{C}$} & \multicolumn{5}{|c|}{ MHB at $44^{\circ} \mathrm{C}$} \\
\hline Species & 5.5 & 6.5 & 7 & $7.5^{*}$ & 8.5 & 5.5 & 6.5 & $7 *$ & 7.5 & 8.5 \\
\hline E. coli KGPM & $0.02 \pm 0.00$ & $0.65 \pm 0.03$ & $0.78 \pm 0.02$ & $1.07 \pm 0.02$ & $1.38 \pm 0.07$ & $0.01 \pm 0.00$ & $0.94 \pm 0.36$ & $0.71 \pm 0.00$ & $0.72 \pm 0.00$ & $0.17 \pm 0.01$ \\
\hline E. coli KGPMF 17 & $0.03 \pm 0.00$ & $0.62 \pm 0.26$ & $0.82 \pm 0.25$ & $1.07 \pm 0.02$ & $1.13 \pm 0.04$ & $0.02 \pm 0.00$ & $0.29 \pm 0.05$ & $0.24 \pm 0.04$ & $0.21 \pm 0.04$ & $0.12 \pm 0.02$ \\
\hline E. coli ATCC 25922 & $0.02 \pm 0.00$ & $0.82 \pm 0.02$ & $0.87 \pm 0.01$ & $0.94 \pm 0.02$ & $1.38 \pm 0.02$ & $0.04 \pm 0.00$ & $0.47 \pm 0.01$ & $0.37 \pm 0.00$ & $0.32 \pm 0.002$ & $0.26 \pm 0.12$ \\
\hline
\end{tabular}

Values are presented as mean \pm standard deviation measured at $600 \mathrm{~nm}$; * growth control.

Table 2. The effect of different concentrations of $\mathrm{NaCl}$ on the planktonic growth.

\begin{tabular}{|c|c|c|c|c|c|c|c|}
\hline \multirow[b]{2}{*}{ Species } & \multicolumn{3}{|c|}{ TSB at $37^{\circ} \mathrm{C}$} & \multicolumn{4}{|c|}{ MHB at $37^{\circ} \mathrm{C}$} \\
\hline & $4 \% *$ & $6.5 \%$ & $8 \%$ & PMHB* & $4 \%$ & $6.5 \%$ & $8 \%$ \\
\hline E. coli KGPMF 16 & $0.72 \pm 0.01$ & $0.31 \pm 0.02$ & $0.07 \pm 0.00$ & $0.80 \pm 0.01$ & $0.19 \pm 0.00$ & $0.07 \pm 0.00$ & $0.02 \pm 0.00$ \\
\hline E. coli KGPMF 17 & $1.15 \pm 0.02$ & $0.44 \pm 0.06$ & $0.12 \pm 0.01$ & $0.70 \pm 0.03$ & $0.24 \pm 0.03$ & $0.09 \pm 0.02$ & $0.02 \pm 0.00$ \\
\hline \multirow[t]{2}{*}{ E. coli ATCC 25922} & $1.58 \pm 0.26$ & $0.86 \pm 0.03$ & $0.42 \pm 0.02$ & $0.75 \pm 0.01$ & $0.16 \pm 0.00$ & $0.02 \pm 0.00$ & $0.02 \pm 0.00$ \\
\hline & & \multicolumn{2}{|c|}{ TSB at $44^{\circ} \mathrm{C}$} & \multicolumn{4}{|c|}{ MHB at $44^{\circ} \mathrm{C}$} \\
\hline Species & $4 \% *$ & $6.5 \%$ & $8 \%$ & PMHB* & $4 \%$ & $6.5 \%$ & $8 \%$ \\
\hline E. coli KGPMF 16 & $0.60 \pm 0.02$ & $0.06 \pm 0.02$ & $0.03 \pm 0.00$ & $0.71 \pm 0.00$ & $0.06 \pm 0.02$ & $0.03 \pm 0.00$ & n.g. \\
\hline E. coli KGPMF 17 & $0.54 \pm 0.00$ & $0.07 \pm 0.01$ & $0.05 \pm 0.01$ & $0.24 \pm 0.04$ & $0.06 \pm 0.00$ & $0.03 \pm 0.00$ & n.g. \\
\hline E. coli ATCC 25922 & $0.62 \pm 0.00$ & $0.54 \pm 0.03$ & $0.12 \pm 0.02$ & $0.37 \pm 0.00$ & $0.12 \pm 0.00$ & $0.04 \pm 0.00$ & $0.01 \pm 0.00$ \\
\hline
\end{tabular}

Values are presented as mean \pm standard deviation measured at $600 \mathrm{~nm}$; n.g.- no growth; *growth control; PMHB-pure MHB- growth control. 
Table 3. The effect of different concentrations of glucose on the planktonic growth.

\begin{tabular}{|c|c|c|c|c|c|c|c|c|c|c|}
\hline \multirow[b]{2}{*}{ Species } & \multicolumn{5}{|c|}{ TSB at $37^{\circ} \mathrm{C}$} & \multicolumn{5}{|c|}{ MHB at $37^{\circ} \mathrm{C}$} \\
\hline & $0.25 \% *$ & $0.5 \%$ & $1.5 \%$ & $2.5 \%$ & $3.5 \%$ & PMHB* & $0.5 \%$ & $1.5 \%$ & $2.5 \%$ & $3.5 \%$ \\
\hline E. coli KGPMF 16 & $1.04 \pm 0.01$ & $0.84 \pm 0.01$ & $0.81 \pm 0.02$ & $0.73 \pm 0.00$ & $0.68 \pm 0.01$ & $0.80 \pm 0.01$ & $0.63 \pm 0.03$ & $0.63 \pm 0.03$ & $0.72 \pm 0.04$ & $0.65 \pm 0.12$ \\
\hline E. coli KGPMF 17 & $1.64 \pm 0.00$ & $1.29 \pm 0.00$ & $1.21 \pm 0.01$ & $1.08 \pm 0.00$ & $1.15 \pm 0.01$ & $0.70 \pm 0.03$ & $0.91 \pm 0.02$ & $0.69 \pm 0.03$ & $0.80 \pm 0.02$ & $0.74 \pm 0.03$ \\
\hline E. coli ATCC 25922 & $1.72 \pm 0.02$ & $1.19 \pm 0.04$ & $1.15 \pm 0.01$ & $1.06 \pm 0.02$ & $1.03 \pm 0.02$ & $0.75 \pm 0.01$ & $0.51 \pm 0.00$ & $0.55 \pm 0.01$ & $0.75 \pm 0.00$ & $0.52 \pm 0.03$ \\
\hline & \multicolumn{5}{|c|}{ TSB at $44{ }^{\circ} \mathrm{C}$} & \multicolumn{5}{|c|}{ MHB at $44^{\circ} \mathrm{C}$} \\
\hline Species & $0.25 \%$ * & $0.5 \%$ & $1.5 \%$ & $2.5 \%$ & $3.5 \%$ & PMHB* & $0.5 \%$ & $1.5 \%$ & $2.5 \%$ & $3.5 \%$ \\
\hline E. coli KGPMF 16 & $1.07 \pm 0.02$ & $0.95 \pm 0.03$ & $0.95 \pm 0.02$ & $0.86 \pm 0.01$ & $0.81 \pm 0.02$ & $0.71 \pm 0.00$ & $0.63 \pm 0.03$ & $0.67 \pm 0.02$ & $0.76 \pm 0.05$ & $0.72 \pm 0.04$ \\
\hline E. coli ATCC 25922 & $0.94 \pm 0.02$ & $0.98 \pm 0.04$ & $0.93 \pm 0.02$ & $0.84 \pm 0.06$ & $0.65 \pm 0.44$ & $0.37 \pm 0.00$ & $0.63 \pm 0.02$ & $0.65 \pm 0.05$ & $0.44 \pm 0.04$ & $0.51 \pm 0.10$ \\
\hline
\end{tabular}

Values are presented as mean \pm standard deviation measured at $600 \mathrm{~nm}$; * growth control; PMHB-pure MHB- growth control.

Table 4. The effect of different concentrations of lactose on the planktonic growth.

\begin{tabular}{|c|c|c|c|c|c|c|c|c|c|c|}
\hline \multirow[b]{2}{*}{ Species } & \multicolumn{5}{|c|}{ TSB at $37{ }^{\circ} \mathrm{C}$} & \multicolumn{5}{|c|}{ MHB at $37^{\circ} \mathrm{C}$} \\
\hline & $0.25 \%^{1}$ & $0.5 \%{ }^{*}$ & $1.5 \%^{*}$ & $2.5 \%{ }^{*}$ & $3.5 \%{ }^{*}$ & PMH & $0.5 \%$ & $1.5 \%$ & $2.5 \%$ & $3.5 \%$ \\
\hline E. coli KGPMF 16 & $1.04 \pm 0.01$ & $0.99 \pm 0.00$ & $0.90 \pm 0.00$ & $0.84 \pm 0.00$ & $0.76 \pm 0.01$ & $0.80 \pm 0.01$ & $0.80 \pm 0.07$ & $0.70 \pm 0.00$ & $0.70 \pm 0.01$ & $0.70 \pm 0.01$ \\
\hline E. coli KGPMF 17 & $1.64 \pm 0.00$ & $1.67 \pm 0.00$ & $1.62 \pm 0.00$ & $1.53 \pm 0.00$ & $1.44 \pm 0.00$ & $0.70 \pm 0.03$ & $1.10 \pm 0.03$ & $0.92 \pm 0.02$ & $0.84 \pm 0.01$ & $0.85 \pm 0.00$ \\
\hline E. coli ATCC 25922 & $1.72 \pm 0.02$ & $1.26 \pm 0.01$ & $1.14 \pm 0.01$ & $1.09 \pm 0.02$ & $1.07 \pm 0.03$ & $0.75 \pm 0.01$ & $0.66 \pm 0.03$ & $0.66 \pm 0.02$ & $0.63 \pm 0.02$ & $0.57 \pm 0.01$ \\
\hline & \multicolumn{5}{|c|}{ TSB at $44{ }^{\circ} \mathrm{C}$} & \multicolumn{5}{|c|}{ MHB at $44^{\circ} \mathrm{C}$} \\
\hline Species & $0.25 \%^{1}$ & $0.5 \% *$ & $1.5 \% *$ & $2.5 \% *$ & $3.5 \% *$ & PMH & $0.5 \%$ & $1.5 \%$ & $2.5 \%$ & $3.5 \%$ \\
\hline E. coli KGPMF 16 & $1.07 \pm 0.02$ & $0.88 \pm 0.01$ & $0.79 \pm 0-02$ & $0.78 \pm 0.03$ & $0.74 \pm 0.01$ & $0.71 \pm 0.00$ & $0.49 \pm 0.08$ & $0.52 \pm 0.04$ & $0.53 \pm 0.08$ & $0.55 \pm 0.04$ \\
\hline E. coli KGPMF 17 & $1.07 \pm 0.02$ & $0.89 \pm 0.01$ & $0.80 \pm 0.00$ & $0.78 \pm .001$ & $0.73 \pm 0.00$ & $0.24 \pm 0.04$ & $0.56 \pm 0.10$ & $0.57 \pm 0.07$ & $0.53 \pm 0.06$ & $0.53 \pm 0.12$ \\
\hline E. coli ATCC 25922 & $0.94 \pm 0.02$ & $1.10 \pm 0.01$ & $1.01 \pm 0.05$ & $0.99 \pm 0.03$ & $0.87 \pm 0.02$ & $0.37 \pm 0.00$ & $0.51 \pm 0.03$ & $0.52 \pm 0.05$ & $0.51 \pm 0.04$ & $0.54 \pm 0.04$ \\
\hline
\end{tabular}


In TSB containing different concentrations of lactose, at $37{ }^{\circ} \mathrm{C}$ the growth of $E$. coli KGPMF 16 and E. coli ATCC 25922 was reduced, while growth of E. coli KGPMF 17 was stimulated only in $0.5 \%$ of lactose. In MHB with different concentrations of lactose, at $37{ }^{\circ} \mathrm{C}$ the growth of E. coli KGPMF 17 was stimulated, while the growth of E. coli KGPMF 16 and E. coli ATCC 25922 were reduced. Only E. coli KGPMF 16 on $0.5 \%$ of lactose give the same value as in growth control.

In TSB containing lactose, at $44{ }^{\circ} \mathrm{C}$ the growth of E. coli KGPMF 16 and E. coli KGPMF 17 was reduced, while the growth of E. coli ATCC 25922 was stimulated in all tested concentrations, except in $3.5 \%$. In MHB containing lactose, at $44{ }^{\circ} \mathrm{C}$ the growth of $E$. coli KGPMF 16 was reduced, while the growth of E. coli KGPMF 17 and E. coli ATCC 25922 was stimulated (Tab. 4).

\section{Determination of antibiofilm activity}

\section{Pellicle test}

E. coli KGPMF 16, and E. coli KGPMF 17 were tested on the ability to form pellicle in TSB and MHB at $37{ }^{\circ} \mathrm{C}$. According to the results, E. coli KGPMF 16 and E. coli KGPMF 17 exhibited no ability to form pellicle in TSB or in MHB.

\section{Biofilm formation}

Bacteria isolated from traditionally made cheese were tested on the ability to form biofilm in two different media, at three temperatures $\left(4{ }^{\circ} \mathrm{C}, 37{ }^{\circ} \mathrm{C}, 44{ }^{\circ} \mathrm{C}\right)$. After the incubation $(48 \mathrm{~h})$, it was noticed that none of the tested bacteria showed ability to form biofilm at $4{ }^{\circ} \mathrm{C}, 37{ }^{\circ} \mathrm{C}, 44{ }^{\circ} \mathrm{C}$ in MHB. It was also noticed that only E. coli KGPMF 17 demonstrated the ability to form biofilm in TSB at $37^{\circ} \mathrm{C}$.

\section{The influence of different $\mathrm{pH}, \mathrm{NaCl}$, glucose and lactose concentrations on the biofilm formation and formed biofilm in TSB}

On the biofilm formation of E. coli KGPMF 17, $\mathrm{pH} 5.5$ showed stimulating effect, while in $\mathrm{pH} 6.5$ and 8.5 biofilm was reduced. In $\mathrm{pH} 7$, biofilm formation was equal to the biofilm formation of positive control. The growth of formed biofilm was stimulated in all $\mathrm{pH}$ values (Fig. 1).

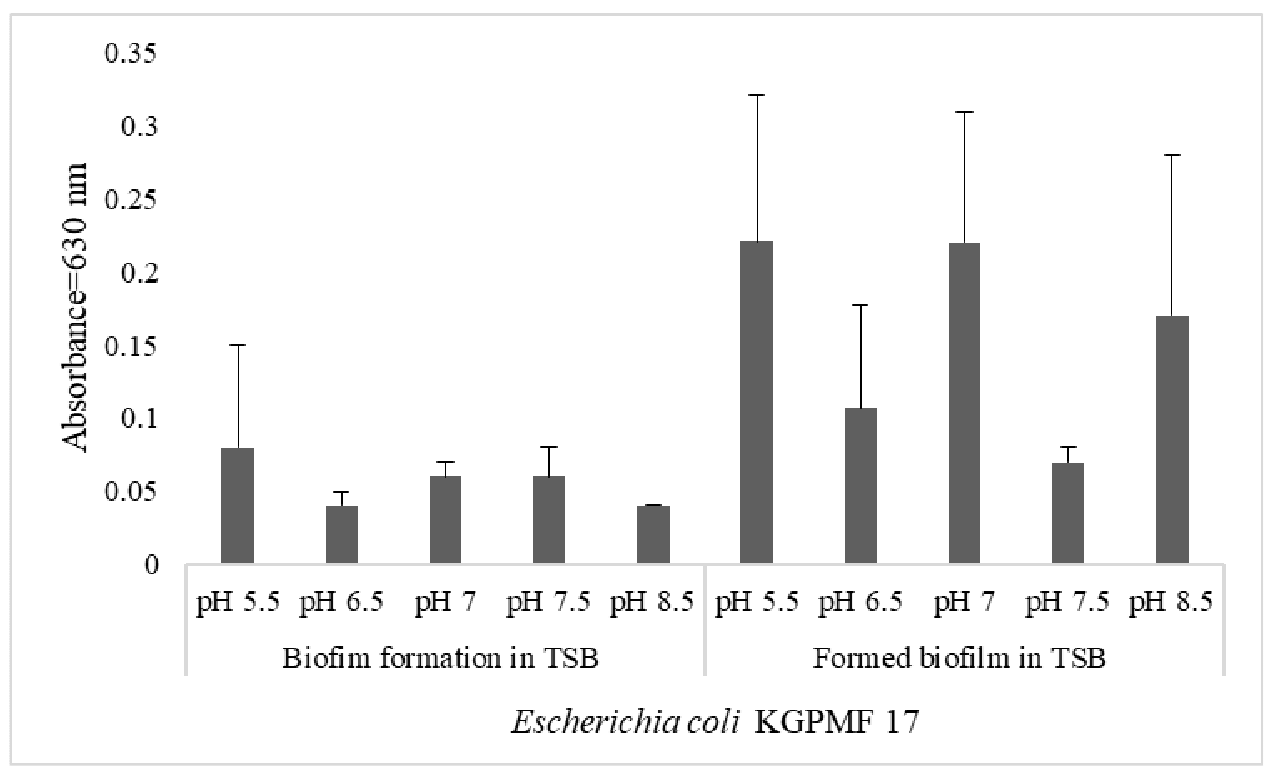

Figure 1. The influence of $\mathrm{pH}$ on the biofilm formation and formed biofilm (*growth control). 
All concentrations of salt produced inhibitory effect on the biofilm formation of E. coli KGPMF 17, compared to the control (growth at 4\%). All concentrations of salt demonstrated stimulating effect on the formed biofilm (Fig. 2).

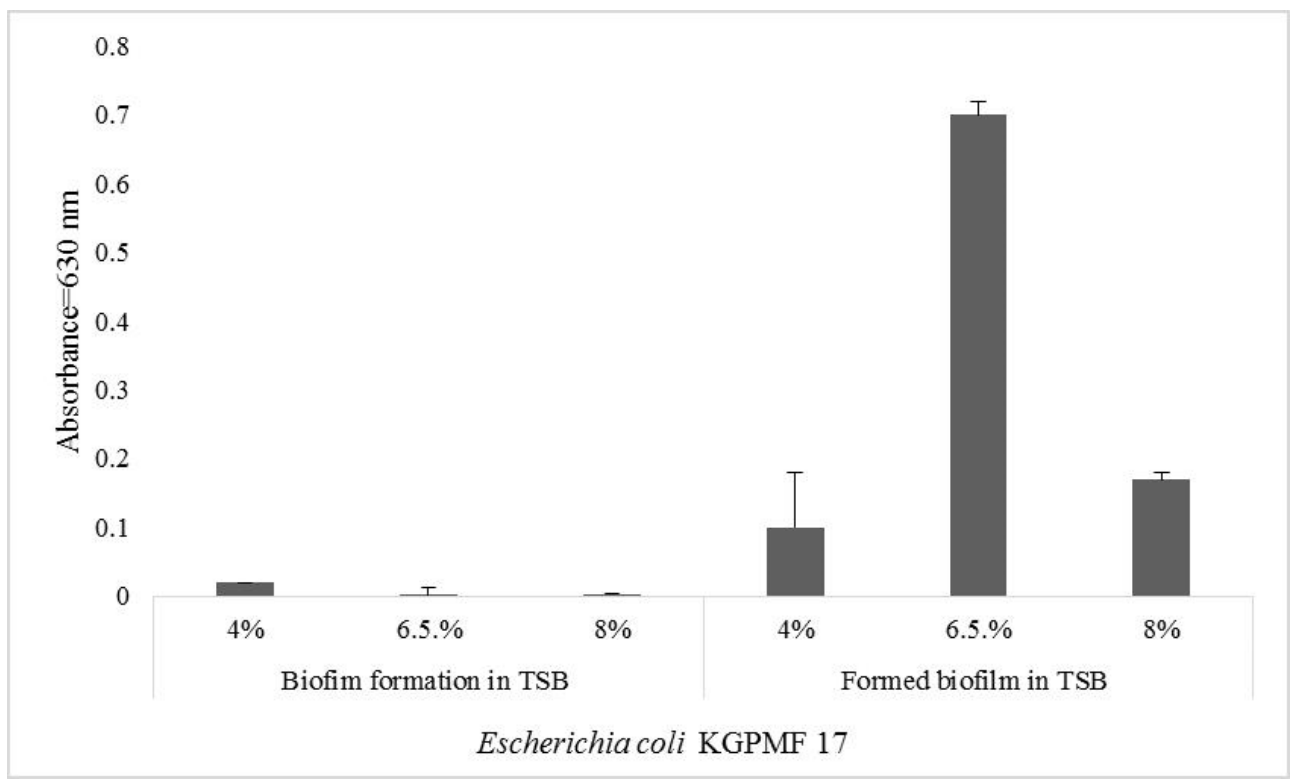

Figure 2. The influence of $\mathrm{NaCl}$ on the biofilm formation and formed biofilm (*growth control at $4 \%$ ).

All tested concentrations of glucose showed inhibitory effect on the biofilm formation, except $0.5 \%$ glucose, where biofilm formation was equal to the growth control. $0.5 \%$ glucose demonstrated stimulating effect on the formed biofilm, $1.5 \%$ showed no influence on the formed biofilm, while higher concentrations of glucose demonstrated the ability to reduce the formed biofilm (Fig. 3).

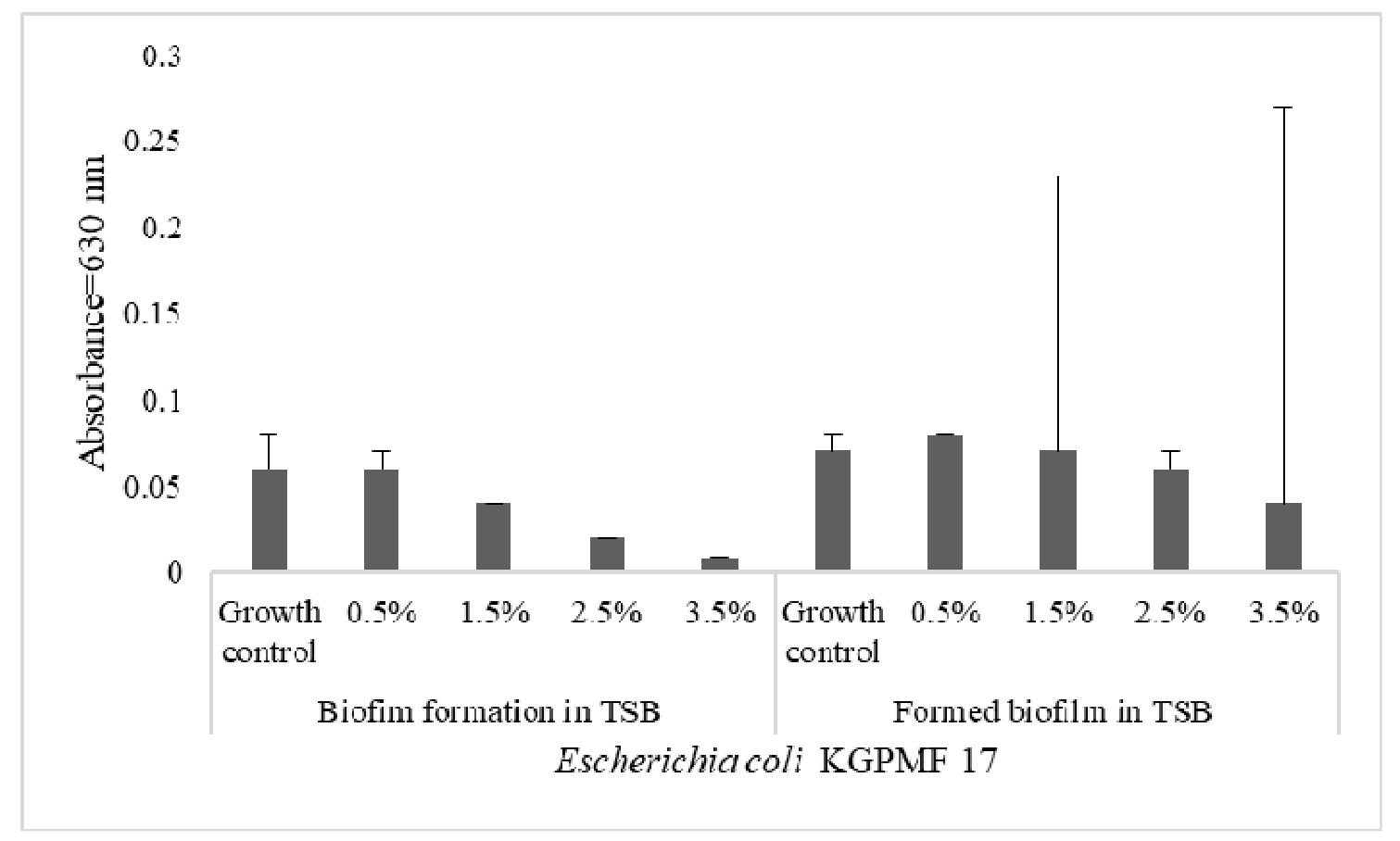

Figure 3. The influence of different concentrations of glucose on the biofilm formation and formed biofilm. 
On the biofilm formation of E. coli KGPMF 17, $0.5 \%$ lactose, showed no influence. On the biofilm formation, $2.5 \%$ lactose demonstrated stimulating effect, while $1.5 \%$ and $3.5 \%$ lactose showed inhibitory effect on the biofilm formation. All concentrations of lactose showed stimulating effect on the formed biofilm (Fig. 4).

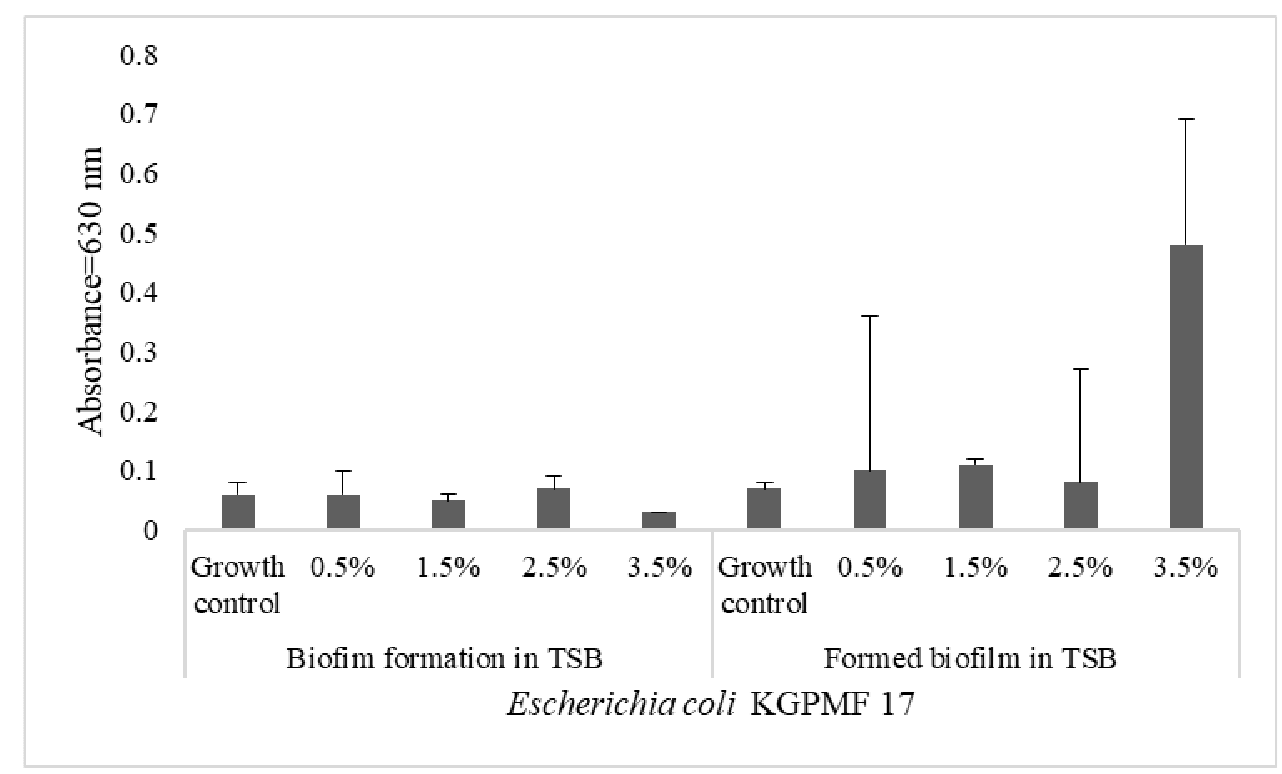

Figure 4. The influence of different concentrations of lactose on the biofilm formation and formed biofilm.

\section{DISCUSSION}

In this study, for the first time, the planktonic growth of E. coli KGPMF 16 and E. coli KGPMF 17 (isolated from Serbian cheese (Sokobanja region) made in a traditional way) was investigated.

It was noted that the growth was higher in TSB at $37{ }^{\circ} \mathrm{C}$. The acidic medium was a limiting factor for the growth of E. coli KGPMF 16 and E. coli KGPMF 17, while the basic medium was more suitable for the growth. Salt was limiting factor for the planktonic growth of $E$. coli KGPMF 16 and E. coli KGPMF 17. Higher salt concentrations increased osmolarity of the medium, which led to hyper osmotic shock of $E$. coli cells causing the growth suppression. The significance of increasing the salt concentration of the medium for the growth of $E$. coli became more apparent when the temperature was raised from $37{ }^{\circ} \mathrm{C}$ to 44 ${ }^{\circ} \mathrm{C}$. It was concluded that increasing the salt concentration in the medium partially surmounted the inhibition of growth of $E$. coli at high temperature. One of studies that examined the combined effect of salt and heat treatment on the bacterial growth were conducted (ABDULKARIM et al., 2009). It was already established that high salt concentration, which increases osmolarity of the medium, also increasing the temperature, so both of this conditions limit the growth of bacteria (SCOTT, 1989; TROLLER, 1986). Based on the results, it could be concluded that the planktonic growth of tested bacteria was more stimulated in the presence of lactose than glucose, while different salt concentrations demonstrated reducing effect on the planktonic growth.

In our investigation, E. coli KGPMF 16 and E. coli KGPMF 17 demonstrated limited growth in TSB with different concentrations of glucose and lactose, at $37{ }^{\circ} \mathrm{C}$ and at $44{ }^{\circ} \mathrm{C}$. In MHB with some concentrations of glucose and lactose, at $37{ }^{\circ} \mathrm{C}$ and at $44{ }^{\circ} \mathrm{C}$, the growth was stimulated. The growth control was higher in the presence of lactose than in the presence of glucose, which was expected, due to the origin of these bacteria. 
In vitro biofilm formation of $E$. coli is variable and depends on the growth conditions (REISNER et al., 2006). Adding glucose to the medium at $37{ }^{\circ} \mathrm{C}$ is more significant for the growth than the addition of salts. Glucose provides a carbon source for the bacterial growth and metabolism. According KHANGHOLI and JAMALLI (2016) the influence of sugars and other factors on biofilm formation can depending on the type of bacteria. Sugars has no effect on the bacterial growth. The expression ycfR (multiple stress resistance protein BhsA precursor), which encodes the synthesis of the outer membrane protein, negatively influences biofilm formation of $E$. coli. Removing ycfR reduced the formation of the biofilm five times in the presence of glucose. The protein protects the cell from the various environmental conditions (ZHANG et al., 2007).

However, the addition of the certain concentration of glucose at $44{ }^{\circ} \mathrm{C}$ produced very slight effect on the growth (ABDULKARIM et al., 2009). The differences in the production of biofilms under various environmental and nutritional conditions can be explained by the ability of some microorganisms to respond to external conditions, such as population density, limited nutrients, osmolarity, $\mathrm{pH}$ or composition of the medium. Bacteria in nature live far away from the optimal growth conditions. Therefore, the cell must have the ability to sense, integrate, and respond to a variety of stresses for survival (DRAGOSITS et al., 2013). Bacteria can activate genes responsible for the expression of surface proteins that enable the adhesion and production of EPS (extracellular polymeric substances), which are directly involved in the production of biofilms (FRANK et al., 2007). It is very important to correctly understand metabolic regulation in response to stresses from environmental factors including protein expression, gene expression, and etc (SHIMIZU, 2014). According to TRÉMOULET et al. (2002), E. coli $\mathrm{O} 157: \mathrm{H} 7$ modified the expression of several proteins involved in biofilm growth mode.

\section{CONCLUSION}

Based on the results, it could be concluded that TSB was more suitable for the planktonic growth and biofilm formation of selected bacteria. All $\mathrm{pH}$ values produced stimulating effect on formed biofilm. All concentrations of salt exerted inhibitory effect on the biofilm formation of $E$. coli KGPMF 17, but demonstrated stimulating effect on the formed biofilm. All concentration of lactose demonstrated stimulating effect on the formed biofilm. Further studies need to include the investigation of additional environmental factors on the growth and biofilm formation of E. coli isolated from Sokobanja cheese.

\section{Acknowledgments}

This investigation was supported by the Ministry of Education, Science and Technological Development of the Republic of Serbia (Grant No. 41010).

\section{References:}

[1] Abdulkarim, S.M., FATMAH, A.B., Anderson, J.G. (2009): Effect of salt concentrations on the growth of heat-stressed and unstressed Escherichia coli. Journal of Food, Agriculture \& Environment 7 (3 \& 4): 51-54.

[2] Beloin, C., VAlle, J., LATOuR-Lambert, P., FAure, P., KzREminski, M., BALestrino, D., HaAgensen, J.A., Molin, S., Prensier, G., Arbeille, B., Ghigo, J.M. (2004): 
Global impact of mature biofilm lifestyle on Escherichia coli K-12 gene expression. Molecular Microbiology 51 (3): 659-674. doi: 10.1046/j.1365-2958.2003.03865.x

[3] Boucher, S.N., Slater, E.R., Chamberlain, A.H.L., AdAms, M.R. (1994): Production and viability of coccoid forms of C. jejuni. Journal of Applied Bacteriology 77 (3): 303 307. doi: 10.1111/j.1365-2672. 1994.tb03078.x

[4] Brennhovd, O., Kapperud, G., Langeland, G. (1992): Survey of thermotolerant Campylobacter spp and Yersinia spp in three surface water sources in Norway. International Journal of Food Microbiology 15 (3-4): 327-338. doi: 10.1016/01681605(92)90066-C

[5] Costa, J.C.M., Espeschit, I.F., Pieri, F.A., Benjamin, L.A., Moreira, M.A.S. (2014): Increase in biofilm formation by Escherichia coli under conditions that mimic the mastitic mammary gland. Ciência Rural 44 (4): 666-671. doi: 10.1590/S010384782014000400015

[6] Costerton, J.W., Lewandowski, Z., Caldwell, D.E., Korber, D.R., LapPin-Scott, H.M. (1995): Microbial bioflms. Annual Review of Microbiology 49: 711-745. doi: 10.1146/annurev.mi.49.100195.003431

[7] Domka, J., LeE, J., Bansal, T., Wood, T.K. (2007): Temporal gene expression in Escherichia coli K-12 biofilms. Environmental Microbiology 9 (2): 332-346. doi: 10.1111/j.1462-2920.2006.01143.x

[8] Dragosits, M., Mozhayskiy, V., Quinones-Soto, S., Park J., Tagkopoulos, I. (2013): Evolutionary potential, cross-stress behavior and the genetic basis of acquired stress resistance in Escherichia coli. Molecular Systems Biology 9 (1): 643. doi: $10.1038 / \mathrm{msb} .2012 .76$

[9] Eckburg, P.B., Bik, E.M., Bernstein, C.N., Purdom, E., Dethlefsen, L., SArgent, M., GILL, S.R., NELSON, K.E., RELMAN, D.A. (2005): Diversity of the human intestinal microbial flora. Science 308 (5728): 1635-1638. doi: 10.1126/science. 1110591

[10] Feng, P., Weagant, S., Grant, M. (2002): Enumeration of Escherichia coli and the Coliform Bacteria. In: Bacteriological Analytical Manual, 8th ed. U.S. Food and Drug Administration.

[11] Frank, K.L., Reichert, E.J., PiPer, K.E., Patel, R. (2007): In vitro effects of antimicrobial agents on planktonic and biofilm forms of Staphylococcus lugdunensis clinical isolates. Antimicrobial Agents and Chemotherapy 51 (3): 888-895. doi: 10.1128/AAC.01052-06

[12] Hall-Stoodley, L., Costerton, J.W., Stoodley, P. (2004): Bacterial biofilms: from the natural environment to infectious diseases. Nature Reviews Microbiology 2: 95-108. doi: $10.1038 /$ nrmicro821

[13] Harrison, J.J., Ceri, H., TuRner, R.J. (2007): Multimetal resistance and tolerance in microbial biofilms. Nature Reviews Microbiology 5: 928-938.

doi: $10.1038 /$ nrmicro1774

[14] ISHII, S., SADOWSKY, M.J. (2008): Escherichia coli in the environment: Implications for Water Quality and Human Health. Microbes and Environments 23 (2): 101-108. doi: 10.1264/jsme2.23.101

[15] Khangholi, M., Jamalli A. (2016): The effects of sugars on the biofilm formation of Escherichia coli 185pon stainless steel and polyethylene terephthalate surfaces in a laboratory model. Jundishapur Journal of Microbiology 9 (9): e40137. doi: $10.5812 / \mathrm{jjm} .40137$ 
[16] Mladenović, K.G., Muruzović, M.Ž., Žugić-Petrović, T., Stefanović, O.D., ČOMIĆ, LJ.R. (2018): Isolation and identification of Enterobacteriaceae from traditional Serbian cheese and their physiological characteristics. Journal of Food Safety 38 (1): 19. doi: $10.1111 /$ jfs. 12387

[17] Nesse, L.L., SeKse, C., Berg, K., Johannesen, K.C.S., Solheim, H., Vestgy, L.K., URDAHL A.M. (2014): Potentially pathogenic Escherichia coli can form a biofilm under conditions relevant to the food production chain. Applied and Environmental Microbiology 80 (7): 2042-2049. doi: 10.1128/AEM.03331-13

[18] O'Toole, G.A., Kolter, R. (1998): Initiation of biofilm formation in Pseudomonas fluorescens WCS365 proceeds via multiple, convergent signalling pathways: a genetic analysis. Molecular Microbiology 28 (3): 449-461.

doi: 10.1046/j.1365-2958.1998.00797.x

[19] Reisner, A., Krogfelt, K.A., Klein, B.M., Zechner, E.L., Molin, S. (2006): In vitro biofilm formation of commensal and pathogenic Escherichia coli strains: impact of environmental and genetic factors. Journal of Bacteriology 188 (10): 3572-3581. doi: 10.1128/JB.188.10.3572-3581.2006

[20] Ren, D., BedzyK, L.A., Thomas, S.M., Ye, R.W., Wood, T.K. (2004): Gene expression in Escherichia coli biofilms. Applied Microbiology and Biotechnology 64 (4): 515-524. doi: 10.1007/s00253-003-1517-y

[21] Schembri, M.A., KJÆRgaArd, K., Klemm, P. (2003): Global gene expression in Escherichia coli biofilms. Molecular Microbiology 48 (1): 253-267.

doi: 10.1046/j.1365-2958.2003.03432.x

[22] ScotT, V.N. (1989): Integration of factors to control microbial spoilage of refrigerated foods. Journal of Food Protection 52 (6): 431-435. doi: 10.4315/0362-028X-52.6.431

[23] SHIMIZU, K. (2014): Regulation systems of bacteria such as Escherichia coli in response to nutrient limitation and environmental stresses. Metabolites 4 (1): 1-35. doi: 10.3390/metabo4010001

[24] Trémoulet, F., Duché, O., Namane, A., Martinie, B., Labadie, J.C. (2002): A proteomic study of Escherichia coli O157:H7 NCTC 12900 cultivated in biofilm or in planktonic growth mode. FEMS Microbiology Letters 215 (1): 7-14. doi: 10.1016/S0378-1097(02)00879-0

[25] Troller, J.A. (1986): Water relations of food borne bacterial pathogens - An updated review. Journal of Food Protection 49 (8): 656-670. doi: 10.4315/0362-028X-49.8.656

[26] Vestby, L.K., Møretrø, T., Langsrud, S., Heir, E., Nesse, L.L. (2009): Biofilm forming abilities of Salmonella are correlated with persistence in fish meal-and feed factories. BMC Veterinary Research 5 (20): 1-6. doi: 10.1186/1746-6148-5-20

[27] XU, K.D., McFeters, G.A., Stewart, P.S. (2000): Biofilm resistance to antimicrobial agents. Microbiology 146 (3): 547-549. doi: 10.1099/00221287-146-3-547

[28] Zhang, X.S., Garcia-Contreras, R., Wood, T.K. (2007): YcfR (BhsA) influences Escherichia coli biofilm formation through stress response and surface hydrophobicity. Journal of Bacteriology 189 (8): 3051-3062. doi: 10.1128/JB.01832-06 